P. DESAI, S. S. PFEIFFER, D. L. BOGER* (THE SCRIPPS RESEARCH INSTITUTE, LA JOLLA, USA)

Synthesis of the Chlorofusin Cyclic Peptide: Assignment of the Asparagine Stereochemistry

Org. Lett. 2003, 5, 5047-5050.

\section{Chlorofusin Cyclic Peptide Synthesis}

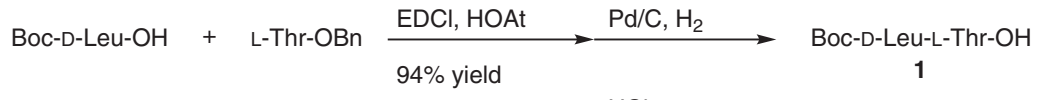

$$
\begin{aligned}
& \text { Boc-D-Leu-OH }+ \text { D-Ada-OMe } \underset{95 \% \text { yield }}{\stackrel{\text { EDCl, HOAt }}{\text { dioxane }} \underset{\text { HCl }}{\longrightarrow}} \begin{array}{c}
\text { H-D-Leu-D-Ada-OMe } \\
2
\end{array} \\
& 1+2 \underset{85 \% \text { yield }}{\stackrel{\text { EDCl, HOAt }}{\longrightarrow} \underset{\text { THF- } \mathrm{H}_{2} \mathrm{O}}{\mathrm{LiOH}}} \text { Boc-D-Leu-L-Thr-D-Leu-D-Ada-OH } \\
& \text { Boc-L-Thr-OH }+ \text { L-Ala-OBn } \underset{86 \% \text { yield }}{\stackrel{\text { EDC,HOAt }}{\text { dioxane }} \underset{\mathrm{HCl}}{\longrightarrow}} \stackrel{\text { H-L-Thr-L-Ala-OBn }}{4}
\end{aligned}
$$

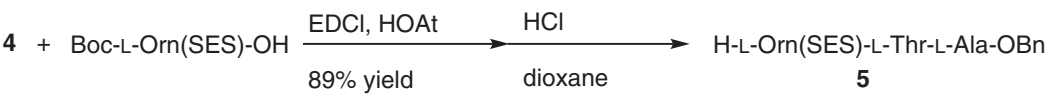

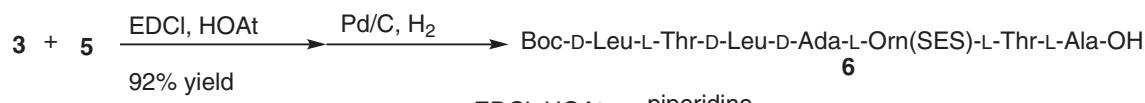

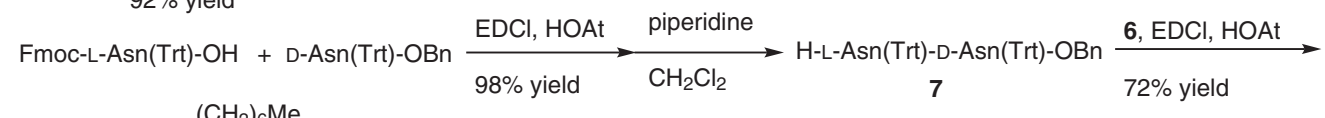

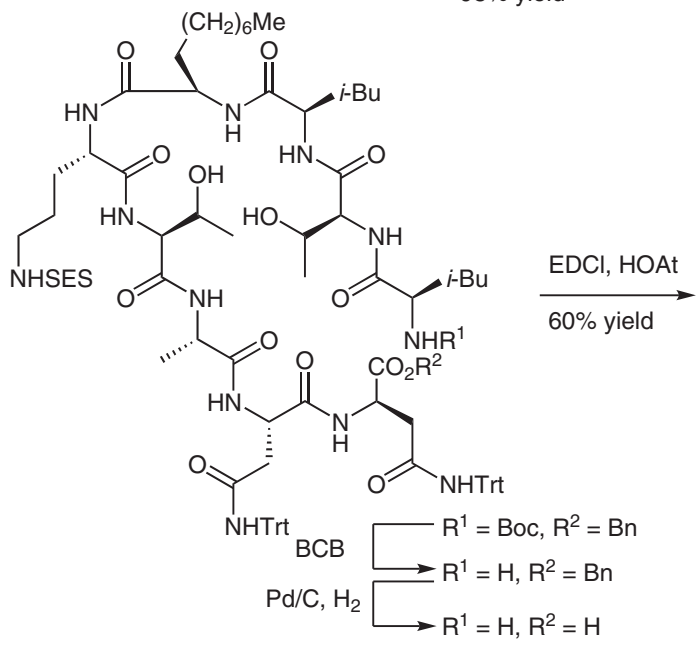

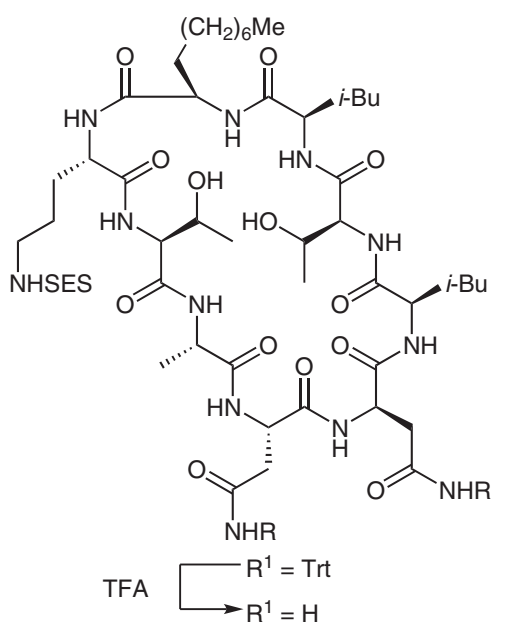

\section{Category}

Peptide Chemistry

\section{Key words}

chlorofusin

cyclic peptides

coupling reagents

macrocycles

\section{$\underset{\text { Classic }}{\min }$}

Significance: Cyclic peptides with unique molecular topologies have attracted attention from the fields of biochemistry and medicinal chemistry. In 2003, Boger and co-workers synthesized the cyclic peptide of chlorofusin, consisting of nine amino acid residues.
Comment: The nine amino acids were assembled from four subunits. Subsequent cyclization using coupling reagents proceeded smoothly to give the 27-membered macrocycle in a moderate yield. 